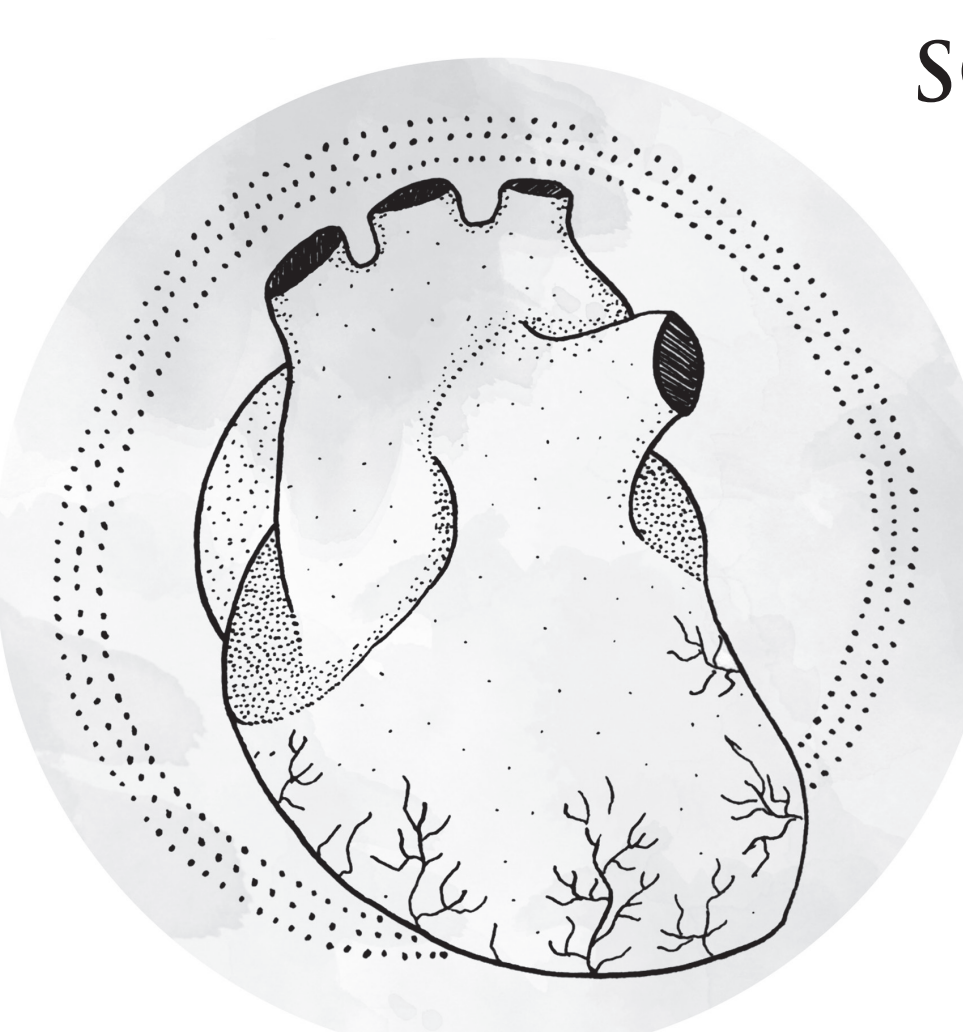

\title{
SOBRE LA POESÍA Y EL ARTE EN EL PENSAMIENTO DE MARTIN HEIDEGGER $^{1}$
}

\author{
ON POETRY AND ART \\ IN THE THOUGHT OF \\ MARTIN HEIDEGGER
}

Por:

\section{Manuel Silva Rodríguez}

Docente de la Escuela de Comunicación Social Universidad del Valle

manuel.silva@,correounivalle.edu.co

Resumen: este texto intenta mostrar algunos alcances que la experiencia del arte tiene en el pensamiento de Martin Heidegger. En particular, expone que, según Heidegger, la experiencia que se tiene del arte es inauguración de un nuevo estado, es el acontecer de una forma de comprender y, por lo tanto, de asignar valor a las cosas. Por esta razón el arte es situado en una posición crítica frente al modo de pensar tradicional de la llamada modernidad, en particular del concepto de verdad que ésta determina y privilegia, de la manera como condiciona nuestra concepción del mundo y nuestra relación con él. El texto muestra, entonces, que la experiencia con el arte y la poesía deviene como dimensión ejemplar de estar en el mundo.

Palabras clave: historicidad, interpretación, lenguaje, obra de arte, poiesis, técnica, verdad.

Abstract: This paper aims to show some scopes that the experience of art has in the thought of Martin Heidegger. In particular, it states that, according to Heidegger, the experience of art is the opening of a new state, it is the event of a way to understand and, therefore, to assign value to things. Therefore art is located in a critical position against the traditional mindset of the so-called modernity, in particular the concept of truth and this determines and privileges, the way it conditions our conception of the world and our relation with him. The text shows, then, that the experience with the art and poetry becomes as exemplary dimension of being in the world.

Keywords: historicity, interpretation, language, artwork, poiesis, technique, truth. 


\section{Introducción}

De igual manera que otros filósofos, anteriores o contemporáneos a él, para Heidegger ocuparse del arte como asunto de la filosofía sobreviene como consecuencia de la búsqueda de soluciones a interrogantes originados en ámbitos filosóficos distintos de la estética. En efecto, si en Ser y tiempo Heidegger volcó toda su energía hacia la preparación de una respuesta a la pregunta por el ser, al modificar la dirección - que no la inquietudque había adoptado en esa obra luego dirigió su atención hacia el arte, pues "la reflexión sobre qué pueda ser el arte está determinada única y exclusivamente a partir de la pregunta por el ser" (Heidegger, 2003a, p. 62). Si bien Heidegger no elaboró una teoría estética propiamente dicha, en el ensayo El origen de la obra de arte (1935-1936), en los textos en que se ocupó de la producción de ciertos poetas (de lengua alemana) y en aquellos escritos en los cuales partió de la poesía para desarrollar su pensamiento, se puede seguir una línea que dibuja una valoración suficientemente coherente acerca de la especificidad de lo artístico y de su significación tanto para la reflexión filosófica como para la experiencia histórica del ser humano.

Lo que intentaré mostrar en este escrito, por consiguiente, es que Heidegger configura una apreciación de la poesía y en general del arte en la cual les asigna un sentido de origen. Origen en cuanto la experiencia que se tiene del arte es inauguración de un nuevo estado, es la experiencia de una forma de comprender singular y, por lo tanto, de asignar valor a las cosas. En consecuencia, el arte es situado en una posición crítica frente al modo de pensar tradicional de la llamada modernidad, en particular del concepto de verdad que ésta determina y privilegia, de la manera como condiciona nuestra concepción del mundo y nuestra relación con él. En última instancia, la relación con el arte es postulada como una experiencia liberadora con respecto al modo de ser y de entender institucionalizado por la racionalidad pragmática. Por lo mismo, el arte y la poesía devienen como dimensión ejemplar: en la experiencia que podemos tener de ellos sería factible reconocer otras posibilidades para la existencia, para el pensar y para la conducta que habitualmente adoptamos con lo que nos es dado. Esta lectura de Heidegger la expondré, por un lado, reconstruyendo a partir de algunos escritos suyos cierto contexto que perfila la forma como él caracterizó la situación de un presente que aún nos alcanza y, por otro, siguiendo algunos de los textos donde abordó los temas del arte y la poesía, a lo largo de los cuales iré recogiendo distintas ideas para ponerlas en contacto. El esfuerzo por comprender sus ideas, sin embargo, no estará ajeno a algunas inquietudes que surgen de algunos términos con los que Heidegger pensó la cuestión del arte. 
En el pensamiento de Heidegger son indisociables arte e historicidad, experiencia y razón. Es preciso, entonces, recordar la manera como en sus textos se describe el momento alcanzado en virtud de la transformación histórica de la racionalidad en Occidente y las ganancias, las pérdidas y los límites que aquella le ha impuesto a la experiencia. La racionalidad antes que en su condición de facultad es entendida en su carácter de órgano funcional. En este sentido, ella provee la estructura que sostiene el edificio de la vida organizada. Es a esa estructura a la que Heidegger llamará metafísica. Ella se extiende a lo largo de los diversos campos de la vida, gracias a los fines a los cuales responden las diversas convenciones y producciones sociales, científicas y culturales, entre otras. Esto lo dice Heidegger en La época de la imagen del mundo, cuando conceptúa que "la metafísica fundamenta una era, desde el momento en que, por medio de una determinada interpretación de lo ente y una determinada concepción de la verdad, le procura a ésta el fundamento de la forma de su esencia. Este fundamento domina por completo todos los fenómenos que caracterizan a dicha era" (2003b, p. 63). Por ahora, notemos que el énfasis está puesto en que un modo de interpretar y un concepto de verdad determinado constituyen el fundamento de la era en la que el mundo se ha hecho imagen.

Según Heidegger, "uno de los fenómenos esenciales de la Edad Moderna es su ciencia" (2003b, p. 63).Y en la consolidación de tal saber científico "la esencia de eso que hoy denominamos ciencia es la investigación”, y el carácter de ésta, como se aprecia de manera más clara en las ciencias de la naturaleza, se orienta hacia la objetivación de los hechos, hacia el encuentro de los medios teóricos y prácticos que permitan fijar y controlar lo potencialmente variable en la experiencia. Heidegger, evidentemente, confronta aquí la concepción positivista de la ciencia: "la investigación de hechos en el ámbito de la naturaleza es, en sí, exposición y preservación de reglas y leyes”. Por demás, esta estructura operativa no se circunscribe sólo a las ciencias de la naturaleza, ya que, a su juicio, este mismo esquema fue trasladado al estudio de la historia, donde "el método tiene como meta representar aquello que es constante y convertir la historia en un objeto", al punto que en la investigación histórica la objetivación se manifiesta como "aquello que es constante en el pasado, aquello que permite que la explicación histórica reúna lo único y lo múltiple, es aquello que siempre ha sido ya, lo comparable" (2003b, p. 67). ${ }^{2}$

Heidegger recalca que, a consecuencia del positivismo reinante, "la ciencia se convierte en investigación única y exclusivamente cuando la verdad se ha transformado en certeza de la representación" (2003b, p. 72). El despliegue de la racionalidad moderna por los más diversos campos de la vida se evidencia en la asunción de la verdad exclusivamente como certeza. Lo común es que antes que con las cosas nos las veamos con las representaciones habituales que de ellas hemos recibido y nos hemos encargado de mantener y reproducir. La visión objetiva, su consecuente objetivación de lo que mira, refleja un tipo de racionalidad que se procura seguridad al trasladar a cada "nueva" experiencia lo "ya conocido". Heidegger afirma que "la 


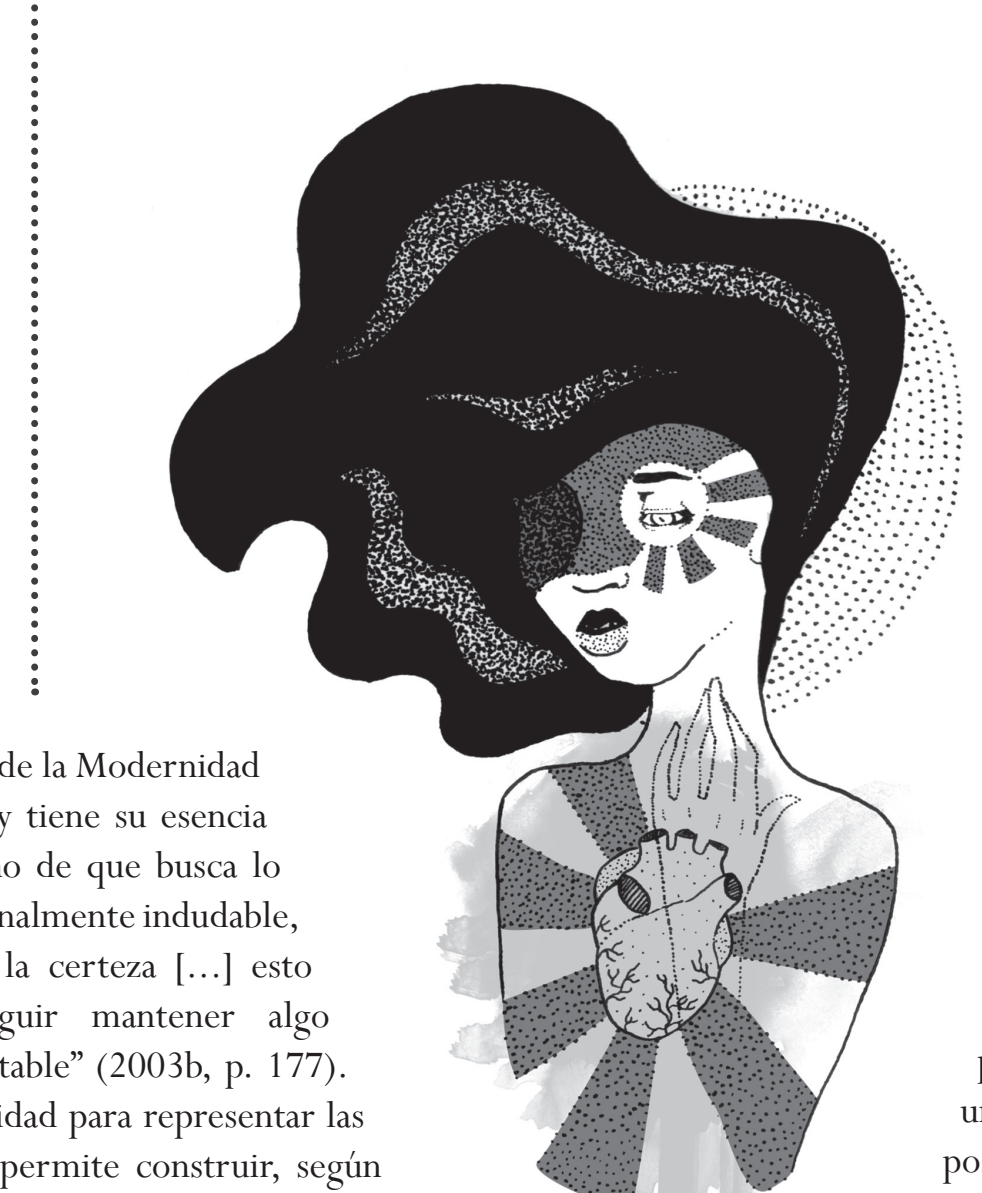

cosas nos permite construir, según Heidegger, el mundo como imagen, pues "es el propio hecho de que el mundo pueda convertirse en imagen lo que caracteriza la esencia de la Edad Moderna” (2003b, p. 74).

Ahora bien, debemos resaltar que Heidegger no niega la importancia que la ciencia pueda tener para la vida organizada. Lo que su pensamiento pone en cuestión es que la concepción de verdad propia de las ciencias de la naturaleza se haya extendido a todos los ámbitos y los domine. En contra de esa tendencia, Heidegger aprecia que tal modo de entender la verdad posee límites. En consecuencia, señala su agotamiento, la necesidad de repensar el concepto de verdad que aquel paradigma instituye y postula uno originario y de mayor amplitud, ya que "la ciencia no es ningún tipo de acontecimiento originario de la verdad, sino siempre la construcción de un ámbito de la verdad" (2003a, p. 45). De allí, entonces, que en la idea del mundo convertido en imagen _distinto del mundo como experiencia que se tiene de las cosas_ - haya un hecho y algunas consecuencias de éste dignas de subrayar. Si "la palabra imagen significa ahora la configuración de la producción representadora”, se trata de una imagen construida por y para el ser humano, pues "en ella el hombre lucha por alcanzar la posición en que puede llegar a ser aquel ente que da la medida a todo ente y pone todas las normas" (2003b, p. 77). Heidegger también suscribe la tesis de que el denominado progreso ha consistido en una suma de esfuerzos por posicionar al ser humano en el centro del mundo, pues desde esa posición los humanos o más exactamente, ciertos individuospueden ordenar y gobernar a su amaño. Es decir, Heidegger observa, como tantos otros, que en nuestra época existe una conexión directa entre razón, concepción de la verdad y dominio.

Para Heidegger, hay un fenómeno que concentra la máxima expresión del punto alcanzado por la metafísica moderna: "la técnica mecanizada sigue siendo hasta ahora el resultado más visible de la esencia de la técnica moderna, la cual es idéntica a la esencia de la metafísica moderna" (2003b, p. 63). Como se nota, Heidegger no habla de la técnica a secas: añade el adjetivo mecanizada o moderna. En principio, suena extraño el agregado "mecanizada" pero, ya veremos, el calificativo no está de más. La técnica mecanizada se define en su papel de expresión operativa, material, de la racionalidad moderna. Heidegger examina este nexo en el ensayo La pregunta por la técnica, donde parte justamente del interrogante que le da título a su escrito y de las respuestas y las definiciones que, en su momento, 
se habían tornado corrientes ante dicha pregunta. De

las maneras como se ha contestado a esa inquietud,

Heidegger resalta el factor común de que la técnica ha sido entendida como medio para lograr objetivos, opinión que, en el fondo, revela que en ella se ha depositado la intención de intervenir, modificar y adecuar las cosas a nuestros fines. La técnica moderna es identificada como manifestación material de voluntad de dominio.

Aunque Heidegger no agota en este punto su examen del asunto —más adelante lo retomaré-, por ahora de ese modo de pensar subrayemos la cuestión que se plantea desde la relación técnicanaturaleza, en la cual se proyecta sobre lo natural una mirada que lo concibe primordialmente como materia útil, como fuente de recursos y de energía eficaces para lograr los fines que el ser humano establece. Vista desde esta óptica, la naturaleza sólo

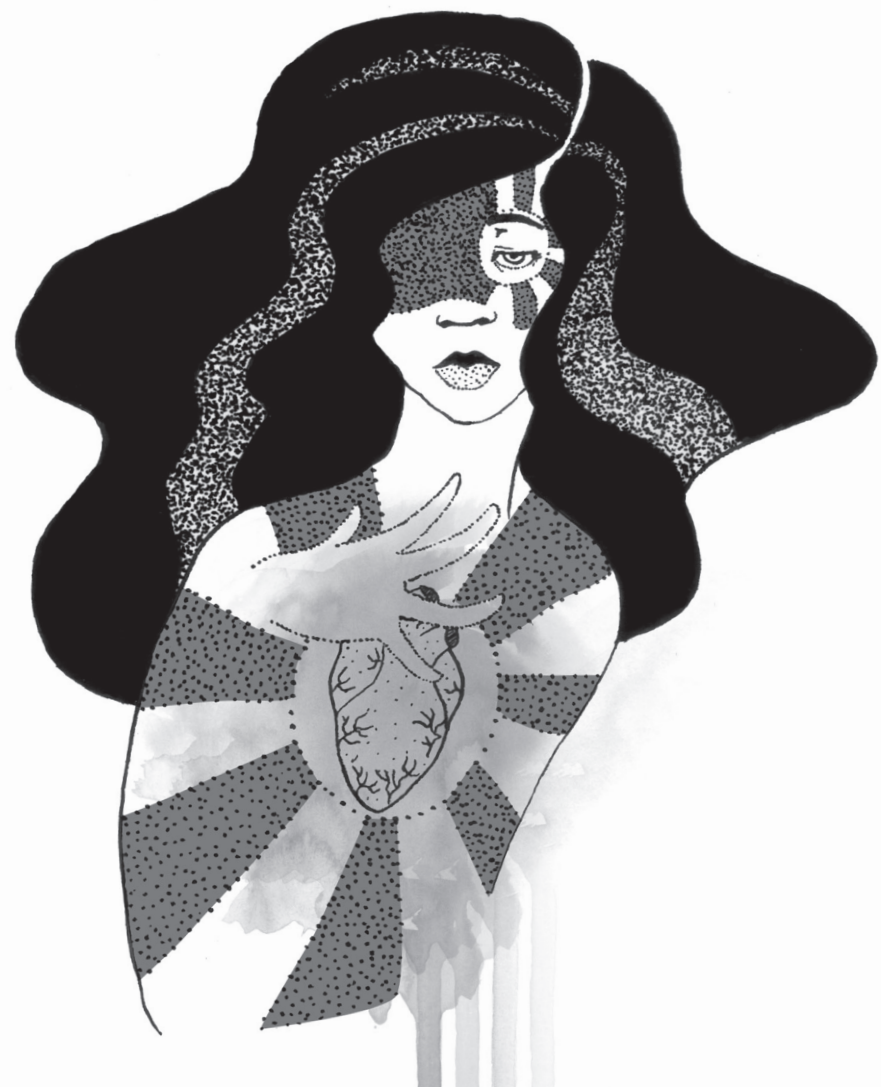
es material. En este contexto, "la técnica moderna es una provocación que pone ante la Naturaleza la exigencia de suministrar energía que como tal pueda ser extraída y almacenada" (Heidegger, 2001, p. 15). Al extremo, dice Heidegger, que el sentido amplio que en la antigüedad tenía el término physis se ha ocultado en nuestro horizonte. En nuestros días, añade, en su lugar tenemos que "el reino de la tierra sale de lo oculto ahora como cuenca de carbón; el suelo, como yacimiento de mineral". Entonces, si el vasto reino de lo natural es reducido a fuente de energía bajo el principio de eficiencia regente para toda acción ajustada a fines, una consecuencia inmediata de tal forma de pensar es que nada potencialmente utilizable es captado por el valor que en sí mismo puede guardar, sino por el que le asigna la ley de la productividad. En última instancia, nos dice Heidegger, sometido como está el ser humano al orden del mundo, él también ha de terminar arrastrado por la lógica de la que es autor. Heidegger vislumbra esta paradoja contemporánea cuando pregunta: "si el hombre está provocado a esto, si se ve solicitado a esto, ¿no pertenecerá entonces también él, y de un modo aún más originario que la Naturaleza, a la categoría de las existencias?" (2001, p. 20). 
Heidegger hacer ver que la raíz de ese estado de cosas se explicita en Nietzsche, si bien éste continuaría inscrito, a su pesar, en la misma línea de la metafísica tradicional. En efecto, según Heidegger ese momento histórico de la razón se advierte en la consideración nietzscheana del nihilismo. En criterio de Heidegger, "el nihilismo, pensado en su esencia, es el movimiento fundamental de la historia de Occidente [...] es el movimiento histórico mundial que conduce a los pueblos de la tierra al ámbito del poder de la Edad Moderna. Por eso no es sólo una manifestación de la edad actual, ni siquiera un producto del siglo XIX" (2003b, p. 163). Para Heidegger, cuando Nietzsche proclama la muerte de Dios introduce el concepto de nihilismo y corona una cima hacia la cual ya se había trazado el camino - "lo hemos matado": el camino recorrido por toda la metafísica occidental. En opinión de Heidegger, el nihilismo revela en su esencia que más allá de la negación de todo valor él consiste en el rechazo de los valores existentes y en la instauración de otros. Nihilismo, en sentido activo, es creación de valores. Vistas así las cosas, Heidegger sostiene que si bien Nietzsche introduce el concepto de nihilismo, la realidad histórica de éste ya existía.

Para Heidegger todo el movimiento de la metafísica occidental ha conducido a un estado de pérdida. En su opinión, "la frase «Dios ha muerto» significa que el mundo suprasensible ha perdido su fuerza efectiva. No procura vida” (2003b, p. 162). A través de este camino Heidegger llega a la afirmación de que la trayectoria de la razón ha llevado a la pérdida del sentido de lo sacro, y en este recorrido la concepción de la vida y de lo verdadero ha sido restringida a una visión material, pragmática. Más que un dios, con la muerte de la idea de Dios se ha extinguido la noción de lo sagrado, la de algo que, aunque intangible, nos sitúa en una condición de proximidad y, por lo tanto, de vínculo con los otros. Heidegger conceptúa que "si Dios, como fundamento suprasensible y meta de todo lo efectivamente real, ha muerto, si el mundo de las ideas ha perdido toda fuerza vinculante y sobre todo toda fuerza capaz de despertar y de construir, entonces ya no queda nada a lo que el hombre pueda atenerse y por lo que pueda guiarse" (2003b, p. 162).

En otros términos, vaciada la noción de lo sagrado luego se habrá de buscar en algún lugar lo que ella procuraba. La apreciación de Heidegger al respecto es que esa búsqueda se ha orientado hacia la propia subjetividad, hacia espacios erigidos por ella. O sea, instancias donde el ser humano aparece como autor y responsable, realizaciones que son obra de su voluntad, la cual se impone como órgano de control y dominio. Según Heidegger para la historia surge un momento crítico cuando "la huida del mundo hacia lo suprasensible es sustituida por el progreso histórico. La meta de una eterna felicidad en el más allá se transforma en la de la dicha terrestre de la mayoría". Él advierte el cambio. O mejor, el reinado del intercambio: "lo creador, antes lo propio del dios bíblico, se convierte en distintivo del quehacer humano. Este crear se acaba mutando en negocio" (2003b, p. 165). 
Ante todo, debemos marcar el énfasis en esa fuerza vinculante atribuida a lo sacro, a una dimensión de la existencia reacia a la objetivación. En lugar de pensarlo en un plano estrictamente teológico, debemos considerar lo sagrado en un orden antropológico, como un aspecto de la existencia humana que, por encima del ordenamiento material y lógico de la vida, reúne y propicia experiencias de cercanía y de cohesión entre los seres humanos y entre ellos y lo demás. Según Heidegger, "la falta de dios sólo significa que ningún dios sigue reuniendo visible y manifiestamente a los hombres y a las cosas en torno así estructurando a partir de esa reunión la historia universal y la estancia de los hombres en ella" (Heidegger, 2003d, p. 199).

Heidegger sostiene que el principio de la metafísica como estructura de toda relación con la naturaleza, con los seres humanos y con el mundo, condujo a un estado de indigencia. A este respecto, es excepcionalmente claro en su ensayo ¿Y para qué poetas?, en el que se aproxima a la obra de Rilke y donde reflexiona sobre la relación entre la poesía y la época moderna. En ese escrito Heidegger pone en evidencia que esta condición de "penuria" de nuestro tiempo se debe esencialmente a la pérdida del sentido de lo sagrado, por lo cual ha sobrevenido la carencia de su experiencia y su consecuente vacío. Esta ausencia es el reverso del mundo consolidado científica y técnicamente. Echando mano del juego que permite la pareja de términos claridad-oscuridad, Heidegger define este tiempo como el anochecer del mundo, época de penumbras donde "la noche del mundo extiende sus tinieblas. La era está determinada por la lejanía del dios, por «la falta de dios»" (2003d, p. 199).

Heidegger asocia un concepto importante a la pérdida del sentido de lo sagrado: "el mundo queda privado de fundamento como aquel que funda" (2003d, pág. 199). Es preciso, entonces, contrastar esta última afirmación con la aportada unos párrafos más atrás. Antes se mostró que "la metafísica fundamenta una era”, y ahora se asevera que el mundo carece de fundamento. Heidegger no da la opción siquiera de pensar en un fundamento falso o equivocado. Simplemente asegura que no lo hay. Es decir, el tipo de experiencia que fomenta la racionalidad moderna no promueve un origen común, no funda vínculos. Con la ausencia de fundamento, del soporte donde se origina, se asienta y se levanta el ordenamiento de la experiencia, de nuestro lugar en el mundo, se eclipsa una perspectiva, un punto de contacto y de cohesión con los otros y con lo que nos rodea. En una época de un potencial tecnológico y de una abundancia de bienes inéditos hasta el siglo XX, la indigencia radica en la pérdida del sentido de vínculo, de nexo con lo externo, con lo otro. Ante este panorama, Heidegger concluye que "la era a la que le falta el fundamento está suspendida sobre el abismo" (2003d, p. 200). 
Estar en el abismo es la pérdida del arraigo, de la pertenencia a un lugar desde el cual le otorgaríamos significado y valor a nuestra propia existencia y a los demás. De acuerdo con Heidegger, la oscuridad que se posa sobre el mundo es resultado de la hipertrofia de una única forma de concebir las cosas. Concepción única que se refleja en ámbitos como el político, el gnoseológico, el ético y el científico.Y por extensión, en las conquistas, los productos y los silencios establecidos por esta manera de pensar. Deambular por el abismo es estar determinado por una conciencia de separación constante, sostener las barreras erigidas entre el sujeto y los otros, cortar el vínculo con la naturaleza entendida como lazo común a todos. En términos más amplios, es crear, disponer y conservar inalterado un orden, un esquema de pensamiento en el que "la producción técnica es la organización de la separación” (2003d, p. 218).

Como se advirtió, el ser humano termina sometido a ese orden: "el hombre que se autoimpone es asimismo, quiéralo o no, sépalo o no, el funcionario de la técnica" (2003d, pág. 218). Por esto, Heidegger ve en la técnica moderna la manifestación palmaria de una razón que reduce el mundo y le obstruye al ser humano la posibilidad de concebir las cosas desde la perspectiva de éstas y establecer un vínculo - emocional, cognoscitivo, ético, afectivo- con ellas. Desde la visualización de estos límites se desprende su afirmación de que "la esencia de la técnica sólo surge a la luz del día lentamente. Ese día es la noche del mundo transformada en mero día técnico. [...] Con él nos amenaza un único invierno infinito. [...] El mundo se torna sin salvación, pierde todo carácter sagrado" (2003d, p. 219).

Habrá que ver qué entiende Heidegger por la esencia de la técnica, que surge, lentamente, en la oscuridad. Pues, ¿cómo se podría contrarrestar la pérdida de fundamento? Queremos subrayar, siguiendo al propio Heidegger, que no se trata de revivir dioses muertos o inventar otros. "El cambio de la era no acontece porque en algún momento irrumpa un nuevo dios o vuelva a resurgir el antiguo desde el trasfondo" (2003d, p. 200). En lugar de una nueva deidad, habría que pensar en la idea de retomar, para basar las relaciones con los otros y con el mundo, esa mirada eclipsada, ese punto de contacto perdido.

III

Lo que quiero destacar es que en el pensamiento de Heidegger, al menos en lo que aquí estoy siguiendo, un punto de contacto se localiza en la dirección del arte. O, propiamente hablando, de la experiencia que la obra de arte nos procuraría. En El origen de la obra de arte Heidegger propone la pregunta sobre qué pueda definir al arte y para intentar establecerlo se remite a la obra como hecho concreto: "para encontrar la esencia del arte [...] buscaremos la obra efectiva y le preguntaremos qué es y cómo es" (2003a, p. 12). Como lo destaca Gadamer ${ }^{3}$, en ese ensayo Heidegger empieza por recoger la línea de análisis en boga en su época, bajo la cual la obra de arte era considerada como un compuesto comprendido por su cualidad tangible, su carácter objetivo de cosa, y un añadido alegórico que remitía hacia una realidad externa a ella. 
Heidegger, por consiguiente, se detiene en los tres modos habituales en que son consideradas las cosas, a saber: como aquello definido por una serie de propiedades, como la suma de las sensaciones que despierta en nosotros el contacto con la cosa y, en última instancia, como la síntesis de materia y forma. Su juicio, finalmente, es que estos tres caminos son insuficientes: ellos constituyen una especie de rodeo que no resuelve la pregunta sobre qué sea la "esencia" de las cosas. Por el contrario, agrega Heidegger, esas vías de acceso a las cosas muestran que a éstas siempre se les ejerce violencia cuando se las considera desde tales puntos de vista. Así Heidegger hace patente lo angosto de esos criterios frente a la obra de arte, ya que si no está claro qué define a las cosas resulta inadecuada la pretensión de reconocer la obra como cosa, en lugar de examinarla desde su peculiaridad, pues "la realidad efectiva de la obra se determina en sus rasgos esenciales a partir de la esencia del ser-obra", "ya no nos planteamos la pregunta por el carácter de cosa de la obra, pues, mientras sigamos planteándola, estaremos tomando inmediata y definitivamente la obra como un objeto dado" (2003a, p. 50).

Sin embargo, Heidegger se detiene atentamente en el tercero de tales modos de apreciar las cosas y señala que si bien "materia y forma es el esquema conceptual por antonomasia para toda estética y teoría del arte", ello no significa que esa pareja "pertenezca originariamente al ámbito del arte y de la obra de arte" (2003a, p. 18). En efecto, Heidegger se ocupa de mostrar que la diferenciación entre materia y forma está presente en otros ámbitos en los cuales ambas categorías están determinadas por una exigencia externa a la cosa, como en el caso de los útiles, donde la utilidad es el factor decisivo en el entramado de los dos conceptos. Precisamente, Heidegger destaca que los útiles son objetos hechos, ocupan una posición intermedia entre la cosa y la obra y no se pueden tomar como igual a ésta.

Entonces, estratégicamente, para definir el carácter del utensilio Heidegger no se remite a un útil como tal, sino que recurre a una obra de arte: a la imagen pictórica de unos útiles, unas botas campesinas pintadas por Van Gogh. Tras recorrer algunos detalles de la pintura y referirse a los zapatos como a objetos reales que tuviera en sus manos, Heidegger asevera que las botas pintadas guardan las huellas del esfuerzo invertido durante la faena con la tierra ${ }^{4}$ Su juicio, por consiguiente, es que la pintura nos muestra que en el contacto del usuario con el útil la utilidad se manifiesta como fiabilidad, como una relación de confianza establecida con la herramienta por parte de quien se sirve del útil, "porque la fiabilidad del utensilio es la única capaz de darle [...] una sensación de protección", pues la fiabilidad "es la primera que nos descubre lo que es de verdad el utensilio” (2003a, p. 24). Heidegger recalca en varios momentos que "ha sido la obra de arte la que nos ha hecho saber lo que es de verdad", ya que en esencia lo que define al utensilio en este caso "Ilega propiamente a la presencia a través de la obra y sólo en ella” (2003a, p. 25). Más allá de los recargados recursos retóricos de Heidegger, lo que debemos retener de 
este pasaje es el retiro brusco que la obra de arte le impondría a quien se dedica a contemplarla. Heidegger reitera que ha sido la pintura la que nos ha dicho en qué reside la verdad del utensilio: "ella es la que ha hablado. Esta proximidad a la obra nos ha llevado bruscamente a un lugar distinto del que ocupamos normalmente" (2003a, p. 25. Las cursivas son mías). Y debemos subrayar que aquí ya está formulada la tesis sobre la obra de arte y la verdad que su experiencia nos proporcionaría, y, a la vez, el núcleo de la postura crítica del pensamiento de Heidegger ante el concepto de verdad reinante en la metafísica occidental. En Heidegger, la importancia de la obra de arte se explica porque con ella viene a la presencia una forma de la verdad o, para formularlo de otra manera, el encuentro con la obra de arte es la experiencia de una verdad muy peculiar.

Heidegger aprecia que en la obra de arte se pondría al descubierto aquello que propiamente sea una cosa y de lo que no daría cuenta el ente que también es la cosa. Así como "el cuadro de Van Gogh es la apertura por la que atisba lo que es de verdad el utensilio", en la obra de arte cada cosa "sale a la luz en el desocultamiento de su ser” (2003a, p. 25). Quiero señalar en este punto el extrañamiento, y a mi modo de ver un problema implicado en este pensamiento sobre el arte, que puede causar el lenguaje de Heidegger. No resultaría muy difícil derivar de estas líneas un sentido próximo a la mística o incluso a la metafísica dualista que sirve de sustento a esa estructura del pensamiento occidental que, justamente, vemos que Heidegger se propone criticar y superar. Según Heidegger,

"en la obra no se trata de la reproducción del ente singular", esto es, de que el arte transcriba qué y cómo es una cosa particular, "sino más bien de la reproducción de la esencia general de las cosas" (2003a, p. 26). Tomadas al pie de la letra, estas frases despiden, paradójicamente, un tufillo platónico y contra Platón. Por una parte, al igual que a Nietzsche, el arte serviría a Heidegger para elaborar una ontología. Lo singular o contingente sería opuesto a lo esencial o permanente. Pero, por otra parte, la obra de arte no sería mera reproducción de un ente singular, es decir, no es copia. Creo que la salida a esta solución estaría en volver la obra a la historia, esto es, justamente a su carácter transitorio y contingente. 
Afrontando el riesgo de redundar en la misma advertencia, para sortear la reserva que nos puede producir el recurrente lenguaje de connotaciones teológicas — "Dios", “divino”, "sagrado”, verdad como "esencia”, etc.—, más aún teniendo en cuenta el alcance del concepto de verdad en este pensamiento, para dejar claro que no se trata de pensar una verdad como una revelación mística se hace necesario enfatizar en lo que sigue. Esto es, que en su configuración la obra permita que las cosas aparezcan como ellas puedan ser, no condicionadas por el significado y, en consecuencia, por el uso que dentro de una formación histórica concreta, fundamentada y organizada por una metafísica del dominio, nosotros les asignamos de manera habitual y al que pretendemos adecuarlas. Esto que vale para el autor de la obra - y para el receptor, como más adelante se señalará - revela la distancia que Heidegger toma ante el concepto de genio ${ }^{5}$ al que vincula con el subjetivismo moderno. En su criterio, la responsabilidad del artista es velar por que la obra sea lograda, que repose en sí misma: "el artista queda reducido a algo indiferente frente a la obra, casi a un simple puente hacia el surgimiento de la obra que se destruye a sí mismo en la creación" (2003a, p. 28).

Entonces, que en la experiencia con el arte podamos experimentar esa manifestación del modo como las cosas pueden ser en sí mismas es posible, según Heidegger, porque ellas se desocultan en la brecha que la obra de arte abre en lo cotidiano. Para Heidegger, es preciso resaltarlo, la obra desoculta porque ella es una hendidura en la cual las cosas se muestran liberadas de la camisa de fuerza en que normalmente las ata nuestra razón. Así es como en la obra "el ente sale a la luz en el desocultamiento de su ser" (2003a, p. 25). Vale decir que la obra extiende ante nosotros un abanico de nuevas posibilidades de ver y entender las cosas. En consecuencia, posibilidades de nosotros reconocernos y de ser frente a lo que nos es exterior. La apertura es tanto puerta por donde lo posible asoma como también despliegue de nuevas alternativas de constitución de sentido. Pero este acontecimiento, insisto, se da en la historia, no por fuera de ella. El mismo Heidegger pregunta: “ $¿ Y$ acaso puede ocurrir la verdad y ser por tanto histórica? Según se suele decir, la verdad es algo intemporal y supratemporal?” (2003a, p. 26). Este despliegue, esta novedad que surge gracias a la obra, es la verdad según Heidegger, ya que "cuando en la obra se produce una apertura de lo ente que permite atisbar lo que es y cómo es, es que está obrando en ella la verdad" (2003a, p. 25). Esta es la cuestión de fondo que anima el esfuerzo teórico de Heidegger acerca del arte. La obra y la experiencia que ella posibilita adquirirían un carácter de modelo o paradigma. El valor de la obra estaría en ese ofrecimiento: "la esencia del arte sería ese ponerse a la obra de la verdad de lo ente” (2003a, p. 25). 
Ahora bien, llegados a este punto ¿cómo entender la tesis de que la verdad se desoculta en la obra de arte y, por lo tanto, que la verdad acontece como desocultamiento? Se ha dicho aquí que actuando como apertura por donde miran las cosas la obra de arte las desoculta y deja asomar lo que pueda constituir su verdad. Según anota Heidegger, "verdad significa esencia de lo verdadero. Pensamos la verdad recordando la palabra que usaban los griegos. Aletheia significa el desocultamiento de lo ente" (2003a, p. 36). En su concepto, el desocultamiento es la esencia, la forma originaria de la verdad ${ }^{6}$ y por ello anterior a la noción de verdad como correspondencia entre un objeto y lo que un sujeto predica de él. En el pensamiento de Heidegger, para que una declaración o juicio corresponda a una cosa, en un momento original esa cosa debió quedar desoculta para poder elaborar un concepto sobre ella. Heidegger consigna que "para que el conocer y la frase que conforma y enuncia el conocimiento puedan adecuarse a la cosa, para que la propia cosa pueda llegar a ser la que fije previamente el enunciado, dicha cosa debe mostrarse como tal”. Entonces, pregunta, “ ¿y cómo se puede mostrar si no es emergiendo ella misma de su ocultamiento, si no es situándose en lo no oculto?" (2003a, p. 37) En este orden de ideas, Gadamer confirma que para Heidegger "el estado desoculto no es sólo el carácter de lo ente en tanto es correctamente conocido. En un sentido más originario, el desocultamiento «acontece», y este acontecer es algo que primeramente hace posible que lo ente esté desoculto y pueda ser conocido correctamente" (Gadamer, 2002).

El desocultamiento, pues, sería para Heidegger la verdad más original. En el caso de la verdad como desocultamiento en la obra de arte, ella consistiría en la experiencia que se tiene al entrar y permanecer en contacto con la obra, en las posibilidades de sentido que se abren en ese momento - no en la corroboración de un dato. En este lugar es pertinente insistir en dos hechos conexos: la preeminencia que Heidegger le otorga a lo posible como una forma de la verdad y al carácter temporal de ésta. En primer término, la experiencia del arte enseña que en él la noción de verdad excede a la consideración habitual: verdad aquí no es verificación, certeza, exactitud científica. La verdad de la que se trata aquí está próxima al reconocimiento de lo posible, que se acepta porque se nos impone y así nos descubre otra manera de ver y de establecer contacto con las cosas. Que captemos sentido en las cosas es previo a la constatación de si ese sentido se puede transformar en un significado verdadero o falso. Al decir de Cristina Lafont Heidegger opera así una ampliación de la noción de verdad al pasar del concepto tradicional como correspondencia a otro en el que la verdad es vinculada “con «lo que tiene sentido» o con lo «posible»". Lafont explica que dentro de este planteamiento "el concepto de verdad ya no se limita a los enunciados (o al conocimiento en sentido estricto): la identificación heideggeriana de «lo verdadero» con «lo posible» constituye, de por sí, una ampliación de la misma a todos los ámbitos de la cultura" (Lafont, 1997, p. 194). La experiencia del arte, entonces, se haría crítica de la tradición metafísica ya que pondría en evidencia que la verdad no debe ser pensada sólo como el concepto fijado de una vez y para siempre. 
En segundo término, por lo tanto, se toma

la verdad como acontecimiento. En

sí misma, esta forma de la verdad es un suceso. Como explica Gadamer, "al remitirse a la obra de arte en la que surge una verdad, Heidegger pretende demostrar justamente que tiene sentido hablar de un acontecer de la verdad" (Gadamer, 2002). Es este acontecer lo que Heidegger sitúa en su formulación de que "en la obra de arte se ha puesto manos a la obra la verdad de lo ente", o sea, que en la obra de arte se pone en ejecución la verdad. Aceptar que la verdad también acontece es inscribirla en el orden temporal: vale anotar, alcanza una dimensión histórica.

Que la verdad acontezca es posible gracias a la capacidad que Heidegger le atribuye a la obra de arte para ella abrir una brecha en nuestro orden pragmático y otorgar un espacio propio a las cosas. El despliegue de esta apertura es el ámbito propio que la obra establece. Heidegger define el establecimiento de este espacio bajo la idea de que "la obra abre un mundo", "ser-obra significa levantar un mundo" (2003a, p. 31). El concepto de mundo, fundamental en esta reflexión sobre el arte, Heidegger lo desconecta de la opinión convencional que lo entiende como la suma de los entes que nos rodean. En cambio, él dota el término con un carácter de intangible: "un mundo no es un objeto que se encuentre frente a nosotros y pueda ser contemplado. Un mundo es lo inobjetivo a lo que estamos sometidos" (2003a, p. 33). Aquí mundo alude a un universo de relaciones donde nosotros, nuestras decisiones, las cosas y los hechos se ordenan por el sentido que allí les es propio. Heidegger dice que un mundo es el espacio donde cada cosa ocupa un lugar, ya que "desde el momento en que un mundo se abre, todas las cosas reciben su parte de lentitud o de premura, de lejanía o proximidad, de amplitud

o estrechez" (2003a, p. 32). Su tesis es que la obra por sí misma levanta un mundo particular. Ella conforma un ámbito donde las cosas configuran o generan sentido en virtud de los valores que ellas mismas instauran en sus relaciones. Al erigir un mundo, entonces, la obra de arte establece unas nuevas condiciones o pautas que permiten nuevas posibilidades de interpretación.
Heidegger asegura, además, que “desde el momento en que la obra levanta un mundo, crea la tierra, esto es, la trae aquí". Es decir, el mundo trae consigo su soporte necesario, la tierra como el lugar de apoyo, la raíz desde donde se yergue. Estas dos imágenes ${ }^{7}$, sobre las que Heidegger va y vuelve constantemente en El origen de la obra de arte, constituyen los rasgos característicos de la obra y, para él, los objetos — en tanto no son obras carecen de ellos. Heidegger afirma que "ambos pertenecen a la unidad del ser-obra”, y por su singularidad y por el vínculo que mantienen hacen posible decir que la verdad acontece en la obra de arte y que aquella no se agota, sino que surja cada vez con fuerza nueva. Mientras el mundo alude a lo "inobjetivo", la tierra comprende lo perceptible sobre lo cual el mundo se alza. La tierra "es lo que hace emerger y da refugio". Si el mundo es el ámbito, la tierra son las cosas de donde aquel emana. Si el mundo se abre y despliega un universo de posibilidades, la tierra ofrece el soporte que a la vez libera y retiene — los hace inagotables - los fundamentos del mundo que se abre. "Aquello hacia donde la obra se retira y eso que hace emerger en esa retirada, es lo que llamamos tierra" (2003a, p. 33). 
Por su parte, Gianni Vattimo aclara que "el mundo es el sistema que los entes constituyen dentro de un determinado horizonte o una apertura del ser", y "la tierra, que no se identifica con la naturaleza (por oposición al mundo como «cultura»), representa más bien, en la obra, la reserva permanente de los significados, la base ontológica del hecho, al que hemos aludido más veces, de que la obra no se deja agotar por ninguna interpretación" (Vattimo, 1993, p. 132). Esta imagen de la tierra explica que la obra de arte sea esquiva, que sugiera interpretaciones y a la vez no se pueda fijar en una sola. La tierra apunta al carácter irreductible de las cosas, en este caso al aspecto material y al aparecer de la obra de arte. La tierra es imagen de las cosas liberadas de la fuerza reductora del signo, de la razón utilitaria.

La peculiaridad del vínculo entre mundo y tierra le concede su rasgo distintivo a la obra. Esto es, mientras el mundo se abre la tierra se recoge. Para Heidegger, en la obra de arte este encuentro se expresaría como un combate instigado en su máxima tensión, "ya que el mundo aspira a estar por encima de la tierra", y "la tierra tiende a englobar el mundo y a introducirlo en su seno". En el pensamiento de Heidegger este es el rasgo del arte: "el ser-obra de la obra consiste en la disputa del combate entre el mundo y la tierra" (2003a, p. 35). Cuando en la obra las cosas erigen un nuevo orden de sentido, tierra y mundo se ponen en contacto y se desata el conflicto entre ambos. Lo propio de la obra es esta tensión. En la obra el material se libera y sugiere. Esta tensión, dice Heidegger, se presenta porque ambas partes se reclaman $y$ pugnan por afirmarse. La pugna del mundo y la tierra constituiría el movimiento del acontecer de la verdad, ya que "la esencia de la verdad es, en sí misma, el combate primigenio en el que se disputa ese centro abierto en el que se adentra lo ente y del que vuelve a salir para refugiarse dentro de sí mismo" (2003a, p. 39). En la obra de arte las cosas se desocultan en tanto ocupan un mundo propio, donde se muestran pero, al mismo tiempo, no es posible retenerlas en una sola significación.

\section{IV}

La obra de arte, que también es producto, es resultado material de un peculiar proceder y se realiza plenamente gracias a una singular forma de mirarla. Ahora es preciso observar en la reflexión de Heidegger, primero, cuál es el proceder que él estima necesario seguir durante la producción de la obra de arte y que, además, hace factible diferenciarla del resto de los objetos y pensarla como creación; y, segundo, cómo se espera que nos relacionemos con la obra. Estos aspectos nos hacen regresar a la cuestión de la técnica. Más atrás quedó dicho que Heidegger califica la técnica moderna como mecanizada, con lo cual la distingue de una noción original que vendría a ser su punto de contraste y, por qué no, nos sugiere, la realización plena de la técnica. Tomando distancia crítica de la concepción de la técnica tan sólo como instrumento, Heidegger recupera la noción griega de tecné. En La pregunta por la técnica, él sostiene que en entre los griegos "tecné no sólo es el nombre para el hacer y el saber hacer del obrero manual sino también para el arte”, y enfatiza en que en sentido prístino tecné significa hacer salir de lo oculto: "la tecné pertenece al traer-ahí-delante, a la poiesis; es algo poético" (2001, p. 14). 
Así Heidegger ata cabos. Tras afirmar que el sentido más originario de la verdad es el desocultamiento, enseguida pregunta "¿qué tiene que ver la esencia de la técnica con el salir de lo oculto? Contestación: es lo mismo. Pues en el salir de lo oculto tiene su fundamento todo traer-ahí-delante" (2001, p. 14). Vista así, la tecné es limpiada de la connotación meramente práctica, como capacidad y habilidad para intervenir y transformar la materia, "lo decisivo de la tecné, pues, no está en absoluto en el hacer y el manejar, ni está en la utilización de medios, sino en el hacer salir de lo oculto" (2001, p. 15). Tecné, sostiene Heidegger, es un saber que "significa haber visto", "captar lo presente como tal", "la esencia del saber reside en la Aletheia, en el desencubrimiento de lo ente" (2003a, p. 43). Por esta vía se abre camino en el terreno del arte su enjuiciamiento crítico a la modernidad y a su expresión en la técnica. A su juicio, la técnica moderna carece o no le importa la esencia de tal saber, ya que "la técnica no es pues un mero medio, la técnica es un modo de salir de lo oculto. Si prestamos atención a esto se nos abrirá una región totalmente distinta para la esencia de la técnica. Es la región del desocultamiento, es decir, de la verdad" (2001, p. 14).

Así es como cierto carácter de la técnica — desde que no sea tomada como mera instrumentación - converge con el arte y, por ello, surge como puente para el acontecer de la verdad. La tecné, la poiesis, refiere el modo como una obra de arte es llevada a punto, pues ella es el proceder que el artista sigue y así "hace que llegue lo ente a su presencia a partir de su aspecto" (2003a, p. 43). Este rasgo marcaría la diferencia de la obra de arte con las demás cosas. Como quedó dicho, en la producción de los útiles la materia y la forma son sometidas al dictado de la eficacia, "debido a que se encuentra determinado por la utilidad y el provecho, el utensilio toma a su servicio aquello en lo que él consiste: la materia [...] El material se considera tanto mejor y más adecuado cuanto menos resistencia opone a sumirse en el ser-utensilio del utensilio" (2003a, p. 32). En cambio, este sentido de la técnica que Heidegger recupera haría posible captar las cosas como son, puesto que este proceder no les impone un concepto preexistente: aunque el artista actúa con las cosas no las violenta con su subjetividad. Así es posible que ellas aparezcan en sí mismas.

La tecné se corresponde con la creación, dice Heidegger, en tanto que "podemos caracterizar el crear como ese dejar que algo emerja, convirtiéndose en algo traído delante, producido" (2003a, p. 43). Heidegger marca ahora la fuerza en la esencia de la obra de arte como puesta en obra de la verdad, de modo que "donde dicho traer delante trae expresamente la apertura de lo ente, es decir, de la verdad, lo traído delante será una obra. Semejante modo de traer delante es el crear" (2003a, p. 45). En la obra las cosas están a su medida, no a la de nuestra necesidad o interés. Justamente el trabajo del artista consiste en servir de puente entre los materiales y la obra, para que ésta adquiera una forma consistente. Su labor, en términos de Heidegger, es compenetrar en la figura de la obra la tierra y permitir que de ésta surja un mundo. Para Heidegger la figura fija la disputa entre mundo y tierra: "el ser-creación de la obra significa la fijación de la verdad en la figura" (2003a, p. 46). En cuanto configuración, la obra está siempre dispuesta a que alguien la mire y descubra el conflicto existente en su interior. 
Ahora bien, el acontecimiento de la verdad en la obra no ocurre por sí mismo ni gratuitamente. Heidegger es claro al afirmar que el desocultamiento no es un estado dado ni una propiedad de las cosas. Para que acontezca alguien lo debe provocar. Esto es, no basta que la obra de arte haya sido hecha por un artista y posea una existencia física: debe haber un receptor que establezca contacto con la obra, que active el conflicto que ella fija entre mundo y tierra y que permanezca como parte de tal disputa. Quedó dicho que esta noción de verdad es activa y temporal: requiere la participación de alguien que se detenga y penetre en la obra para que así se abra un mundo. Sólo así se concreta la obra, pues "tampoco lo creado mismo puede seguir siendo sin sus cuidadores". Heidegger define esta relación como "cuidado" -algunos comentaristas lo refieren como conservación o preservación-: un adentrarse en la obra y compenetrarse con las cosas que ella guarda y el ámbito que éstas levantan. Este cuidar es un demorarse en la obra al que ella misma obliga: "detenerse en esta demora es lo que permite que lo creado sea la obra que es. Dejar que la obra sea una obra es lo que denominamos el cuidado por la obra” (2003a, p. 48). En este punto se hace explícito el valor que Heidegger le concede a la experiencia del arte. Si la obra se concreta como tal durante el "cuidado" es en éste, entonces, que acontece la verdad que ella guarda. La plenitud del arte está en el acontecimiento de la verdad, en la experiencia con la obra.

Aquí la metáfora de la composición de la obra por la pareja tierra/mundo incrementa su sentido. La permanencia "obligada” en la obra se explica por el abrirse y el cerrarse de ella, por el levantamiento de un mundo y a la vez el retirarse de la tierra. La propia dinámica de la obra fuerza a mantenerse en comunicación con ella. Este resguardarse reviste la obra de una peculiaridad que Heidegger nombra como un «que» exclusivo del arte. Aunque él no utiliza la palabra autonomía, bien se puede asociar este «que» a lo que ella denota pues, justamente, las cosas útiles no son autónomas. Su carencia de autonomía da lugar a que nuestra subjetividad las determine. Heidegger precisa que "es verdad «que» el hecho de haber sido fabricado es algo que también forma parte de todo utensilio disponible y en uso. Pero en lugar de aparecer en el utensilio, este «que» desaparece en la utilidad" (2003a, p. 47). Este carácter singular decide la calidad de obra del objeto producido. Hace que éste sobresalga como obra.

Entrar en el mundo de la obra, por consiguiente, nos exige poner en suspenso la lógica que rige nuestra cotidianidad. Mientras de cada cosa sólo pensamos en su para qué, como si sólo estuviera dispuesta para nuestro uso, hay tal costumbre y estrechez en esa mirada que las cosas no nos sorprenden, siempre aparecen reducidas al papel que les asignamos. Lo singular de la obra, en cambio, no es su para qué, sino que sea como es: "por el contrario - aclara Heidegger — , en la obra lo extraordinario es precisamente que sea como tal [...] es el mismo acontecimiento de que la obra sea como tal obra el que proyecta a ésta ante sí misma y la mantiene proyectada en torno a sí” (2003a, p. 47). 
Este reposo en sí misma es la fuerza de la obra, su abrirse y cerrarse, su permanente incitación a pensar a partir de ella. Heidegger ve este reposo como un movimiento intenso generado en el interior de la obra por la unidad conflictiva de mundo y tierra, "es en la intimidad del combate donde tiene su esencia el reposo de la obra que reposa en sí misma” (2003a, p. 35). Así la obra se nos impone y nos abre camino hacia un acontecimiento, hacia una experiencia de la verdad. Al modificar nuestra mirada empezamos el "cuidado" de la obra, porque el "preservarla" exige una transformación en nosotros. Como se subrayó antes, la obra nos lleva bruscamente a un lugar distinto del que ocupamos normalmente, nos "demanda transformar las relaciones habituales con el mundo y la tierra y a partir de ese momento contener el hacer y apreciar, el conocer y contemplar corrientes a fin de demorarnos en la verdad que acontece en la obra” (2003a, p. 48). Tras este cambio sobreviene el extrañamiento. La verdad surge también como extraña a nuestra óptica corriente, pues “cuanto más solitaria se mantiene la obra dentro de sí, fijada en la figura, cuanto más puramente parece cortar todos los vínculos con los hombres [...] tanto más esencialmente emerge lo seguro y desaparece lo que hasta ahora parecía seguro" (2003a, p. 48).

La obra, se ha dicho, es hostil a dejarse fijar en un concepto: no se ajusta al criterio de verdad como correspondencia o corrección. Entrar en la obra es un proceso que "no entraña ninguna violencia", es un saber que "no consiste sólo en un mero conocer o representarse algo", que "ni aplica un saber ni lo decide previamente" (2003a, p. 49). Heidegger insiste en que "la verdad que se muestra en la obra no puede demostrarse ni derivarse de todo lo que se admitía hasta ahora. La obra rebate la exclusividad de la realidad efectiva de lo admitido hasta ahora. Lo que el arte funda no puede nunca, precisamente por eso, verse contrarrestado por lo ya dado y disponible" (2003a, p. 54). Frente a la obra de arte nos sobrecoge el hecho de que ella confronta nuestro punto de vista corriente, ya que se planta como algo nuevo y ajeno a las leyes usuales con las que operamos en el orden cotidiano. A este precio es posible acceder a la forma de la verdad que acontece en el arte. Vattimo recuerda que Heidegger denomina este impacto como "el Stoss, el choque (o schock) producido por la obra”, y precisa que no se debe "confundir a Heidegger con un teórico de la «maravilla» como fin de la poesía. Lo que produce el Stoss en el arte no es un modo particular de ser de la obra (algún carácter estupefaciente), sino el hecho mismo de que esté ahí" (Vattimo, 1993, p. 165). En el encuentro con la obra, podríamos anotar, nos sorprende el esfuerzo que ella nos reclama de abandonar nuestra posición acostumbrada y adentrarnos en las relaciones que las cosas instauran por sí mismas.

Si conformar una obra de arte es "crear como aquel traer delante el desocultamiento de lo ente" y "el cuidado por la obra es, como saber, el lúcido internarse en lo inseguro de la verdad que acontece en la obra", es factible afirmar que ambos momentos son los extremos de una misma conducta o forma de ver: la que hace posible esa experiencia de la verdad. Heidegger define este saber como el poetizar. En su concepto, "la verdad como claro y encubrimiento de lo ente acontece desde el momento en que se poetiza” (2003a, p. 52). En sentido amplio, para Heidegger poetizar designa un comportamiento original que hace posible el desocultamiento 
de las cosas. Poetizar es poiesis. En este pensamiento poetizar no significa tan sólo escribir poemas. Es, ante todo, instaurar una apertura del mundo, un universo de sentido desde el cual las cosas despliegan su potencial. Ahora bien, para Heidegger en nuestro tiempo la poesía es la obra humana que mantiene vigentes las posibilidades del poetizar. En tanto que poetizar es abrir mundo, despejar nuevas vías de comprensión y entendimiento, la poesía es un esfuerzo dedicado a esa tarea. Heidegger aprecia que crear arte, en cualquiera de sus formas, es hacer poesía: "Todo arte es en su esencia poema en tanto que un dejar acontecer la llegada de la verdad de lo ente como tal" (2003a, p. 52).

No obstante, Heidegger estima que "el poema en sentido estricto, ocupa un lugar privilegiado dentro del conjunto de las artes" porque el poema es "la obra del lenguaje". En realidad, el valor que Heidegger encuentra en la poesía y en el arte en general es que ellos son como el lenguaje más prístino. El lenguaje como posibilidad primera y fundacional es apertura de mundo, y en cuanto la obra de arte es apertura por donde asoma la verdad actúa como lenguaje. Ya en El origen de la obra de arte Heidegger sostiene que el lenguaje no es un mero útil confinado a la función de signo: "el lenguaje es el primero que consigue llevar a lo abierto a lo ente” y “donde no está presente ningún lenguaje, por ejemplo en el ser de la piedra, la planta o el animal, tampoco existe ninguna apertura" (2003a, p. 53) ${ }^{8}$. Heidegger insistía en que "es necesario comprender correctamente el concepto de lenguaje" (2003a, p. 53), "la esencia de la Palabra no agota su virtud en eso de ser medio para entenderse" (Heidegger, 1989, p. 25).

Estas son ideas que Heidegger desarrolló después del ensayo sobre El origen de la obra de arte. En efecto, en su Carta sobre el humanismo consignó que la metafísica "se adueñó desde tiempos muy tempranos de la interpretación del lenguaje bajo la forma de la «lógica» y la «gramática» occidentales. Lo que se esconde en tal suceso es algo que hoy sólo podemos adivinar". Desde entonces, asume que "liberar al lenguaje de la gramática para ganar un orden esencial más originario es algo reservado al pensar y poetizar" (Heidegger, 2000). De modo que la poesía por ser la forma del arte que procede directamente con el lenguaje recibe toda la atención de Heidegger. En ella, donde en la palabra las cosas se abren y se presentan en su verdad, el lenguaje se muestra en su carácter primordial, abandona su papel meramente instrumental y, por el contrario, se nos presenta en su posición constitutiva: fundadora de mundo. El mundo surge en el lenguaje. Heidegger conceptúa que "como el lenguaje es aquel acontecimiento en el que se le abre por primera vez al ser humano el ente como ente, por eso la poesía, el poema en sentido restringido, es el poema más originario" (2003a, p. 53). En Heidegger, poesía, verdad y lenguaje no se podrían comprender en toda su dimensión si se toman separados.

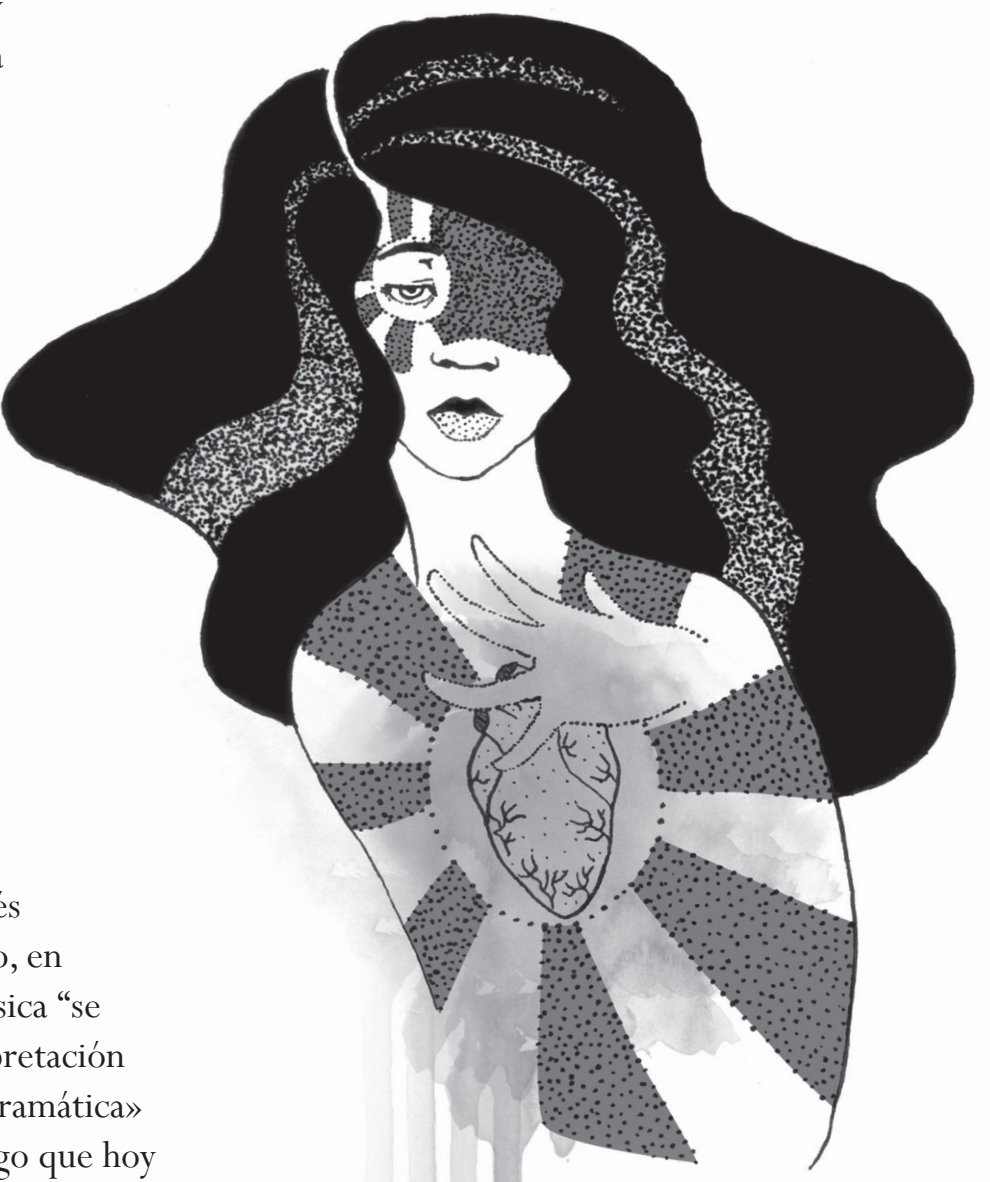


A la luz de este reclamo por una liberación del lenguaje, si aceptamos que crear la obra es el anverso de un comportamiento, debemos aceptar también que de alguna manera su reverso es preservarla. El propio Heidegger sugiere que "no es sólo la creación de la obra la que es poética, sino también, aunque de otra manera, el cuidado de la obra" (2003a, p. 54). Las ideas de Heidegger nos dicen que dar presencia a lo oculto es poetizar, que éste es procurar "un lugar abierto en medio de lo ente en cuya apertura todo es diferente a lo acostumbrado" (2003a, p. 52). En esa medida, la experiencia con la obra testificaría el desprendimiento durante la recepción de la lógica corriente y de la cesión de la palabra a las cosas. Podríamos entender el poetizar como relacionarnos con las cosas de un modo distinto del habitual, como si fuera la primera vez que las encontráramos en nuestro camino $\mathrm{y}$, en lugar de plegarlas a nuestra conveniencia, como el procurar descubrir cómo se nos pueden manifestar.

Precisamente, gracias a una liberación de la lógica regente en el orden práctico es posible que la poesía perciba el mundo de otra manera, pues en ningún caso la poesía sería un capricho del poeta. Heidegger lo advierte al decir que "Hölderlin ha oído que se le decía: «Poetas, sed libres cual golondrinas». Empero, esta libertad no es arbitrariedad sin reglas y deseo con caprichos, sino suprema necesidad" (1989, p. 35). Recordemos que la tecné que describe Heidegger es un saber mirar lo oculto para conducirlo hacia su desocultamiento. Sin el ánimo de dar definiciones reduccionistas y, por lo mismo, inútiles, podríamos imaginar también el poetizar como un saber mirar y escuchar. ¿Saber mirar y escuchar qué? En el pensamiento de Heidegger, con la extinción de lo sagrado en nuestro mundo habitual apenas se pueden vislumbrar las huellas que los dioses dejaron en su retirada. Si aceptamos que con lo sagrado podemos comprender un sentido de proximidad y de comunión entre nosotros y los demás, y entre nosotros y las cosas, entonces desocultar rastros que nos devolvieran un sentido de cercanía y de comunidad sería posible gracias a una mirada capaz de percibir y decir lo ausente.

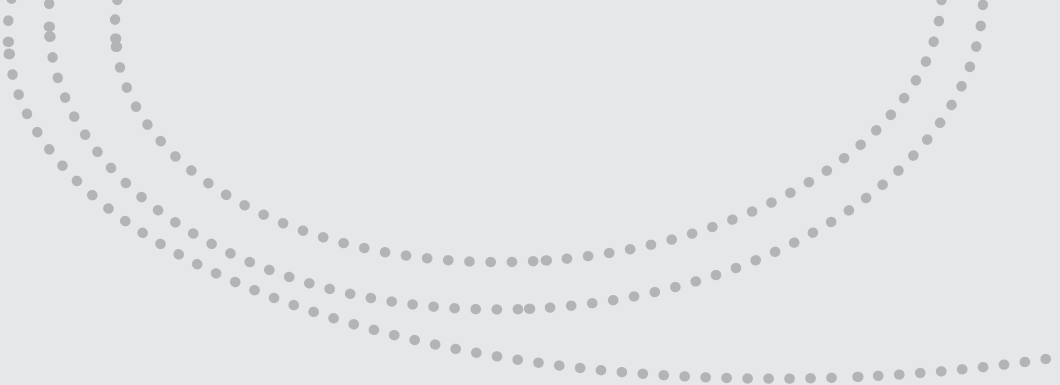

Empero, advierte Heidegger, esta forma de ver no es corriente, se nos hace difícil adoptarla. Según Heidegger, tal visión la poseen los poetas: "ser poeta en tiempos de penuria significa: cantando, prestar atención a los rastros de los dioses huidos. Por eso es por lo que el poeta dice lo sagrado en la noche del mundo" (2003d, p. 201). En rigor, para Heidegger esa capacidad hace al poeta, pues "el decir del Poeta es sorprender estos signos para significarlos, ampliándolos, a su Pueblo. Y este sorprender tales signos es recibirlos, y a la vez darlos de nuevo, porque el poeta columbra ya en «el primer signo» lo Postrimero" (1989, p. 35). Ser poeta, afirma, es ir hasta el abismo abierto en nuestros tiempos, ver dónde está el peligro que acarrea la pérdida de lo sagrado y mostrarlo. Ya que el poeta "audazmente pone en palabras lo visto, para predecir lo que aún no se ha cumplido” (1989, p. 35), la poesía es también un esfuerzo por mantener en la memoria un horizonte de la experiencia y denunciar la necesidad de no olvidarlo y la posibilidad de recuperarlo. De ahí que la poesía y en general el arte nos proporcionen una experiencia de lo posible.

$\mathrm{Al}$ presentarnos las cosas de una nueva forma, al liberar el lenguaje de la gramática, la poesía es valorada como fundación. Por tanto, la obra de arte es fundamento en cuanto que reposando en sí misma es apertura para el acontecimiento de la verdad. Para Heidegger, "el hombre que habita poéticamente lleva todo lo que aparece, tierra y cielo y lo sagrado, a la apariencia estable por sí misma; y que lo preserva todo; lo lleva, en figura de la obra, a un seguro estar. «Mantener todo en pie y por sí mismo» significa: fundar” (Heidegger, 1983, p. 177). 
Es importante precisar que Heidegger introduce este valor de la poesía y del poetizar en su sentido más amplio como fundación en El origen de la obra de arte. Allí le confiere tres atributos a la acción fundadora, a saber: como donar, fundamentar y comenzar. Heidegger aprecia que, en primer lugar, el poema es donación como experiencia que reporta algo nuevo: de la obra surge una verdad hasta entonces desconocida, que se entrega a sus "cuidadores" y que rebasa lo existente hasta entonces. En segundo término, la poesía es fundamento puesto que ella funda un mundo, soporta y acoge en sí misma: en su reposar, la obra de arte sostiene un universo de donde emergen nuevas posibilidades de sentido. Y en tercer lugar, la obra es fundación en cuanto es comienzo, desde ella se establece una manera distinta de ver, de acceder a la experiencia, de comprender lo existente.

En Hölderlin y la esencia de la poesía, Heidegger pregunta “¿qué es lo fundado?: Lo permanente; pero ¿es que lo permanente puede ser fundado? ¿Que no es lo permanente lo desde siempre presente?" (1989, p. 25). A lo que cabe agregar ¿a qué se denomina ahora lo permanente, si más atrás se habló de lo permanente como lo objetivo? Desde luego, aquí es necesario volver a aclarar el sentido que puede sugerir el dejo metafísico de los términos usados. Lo permanente no es una esencia ahistórica ni supratemporal. Vale mejor entender por lo permanente la posibilidad misma de mirar y comprender, en cada momento histórico, de una manera diferente de la establecida y sedimentada. Por esta vía este planteamiento adquiere un sentido crítico: se trataría de una posibilidad de despliegue del lenguaje y de emergencia de una noción de verdad que rebasarían la habitual, aquella restringida a la función de correspondencia entre lo declarado sobre una cosa y la cosa. En este ámbito lo permanente no es lo que fija la voluntad representadora, todo lo contrario, "lo permanente es, justamente, lo que tiene que ser detenido contra la arrebatada corriente" (1989, p. 29), pues “precisamente lo permanente es lo huidizo”, lo que se oculta a nuestra concepción corriente del mundo. Suscribiendo la frase de Hölderlin según la cual lo verdadero lo fijan los poetas, Heidegger dirá que la esencia del poema es la fundación de la verdad.

La cualidad constitutiva del lenguaje se nos presenta en la fundación de la verdad como apertura de mundo, como el nombrar que, más allá de asignarle un nombre a algo o alguien, establece el inicio de un nuevo sentido. Este nombrar, que es lo propio de la poesía, es un dejar libre al lenguaje, a las cosas y a nosotros con respecto a la fuerza del signo. Heidegger llama a esta liberación el "proyectar del poema", su "arrojar" hacia la apertura que despliega la poesía, "el decir que proyecta es poema: es relato del mundo y la tierra" (1989, p. 29) en su disputa. Se explica así que este "nombrar no distribuye títulos, no emplea palabras, sino que llama las cosas a la palabra" (Heidegger, 2002a, p.15). Aquí se comprende la idea de Heidegger de que, junto al pensador, el poeta es el guardián del lenguaje. La poesía es el ámbito donde nos vemos, por decirlo así, cara a cara con el lenguaje, donde estaríamos dentro de él en lugar de limitarlo a la mera función referencial. Por lo mismo, al despojarlo de su carácter funcional, en la poesía se haría evidente que el lenguaje instaura la verdad. 
De ahí que Heidegger afirme que "el arte alcanza su esencia histórica en tanto que fundación”, que diga incluso que el arte funda mundos históricos, ya que "el arte es historia en el esencial sentido de que funda historia" (2003a, p. 56). La funda, se establece como origen, en cuanto desde la experiencia que tenemos del arte éste nos exige que nos miremos desde la verdad que surge allí. Si lo sagrado corresponde a una fuerza vinculante, a su manera el arte también establece vínculos en cuanto funda mundo y así historia: la experiencia del arte haría que compartiéramos ese encuentro con algo nuevo que, a partir de ese momento o así sea por un instante, nos hace ver el mundo con otros ojos. En tanto que acontecer histórico, la experiencia con la obra, el acontecer de la verdad, al fijar su propio orden rompe la manera convencional con la que nos entendemos con las cosas y bajo la cual nos vemos, porque su "carácter de radicalmente nuevo" da lugar a una "discontinuidad o carácter epocal" (Lafont, 1997, p. 196) del surgimiento de la verdad. Como lo explica Lafont, "cuando habla de «fundamentar», Heidegger quiere dar a entender que mediante una «apertura de mundo» se establecen todos los criterios normativos que luego, una vez aquella ha tenido lugar, pueden hacerse valer para medir y enjuiciar los fenómenos que resultan accesibles mediante tal «apertura»"(Lafont, 1997, p. 196). De cierta manera, esta apertura induce a la revisión del modo de ver y de vernos: "para un pueblo histórico, su tierra, el fundamento que se cierra a sí mismo, sobre el que reposa con todo lo que ya es, pero que permanece oculto a nuestros propios ojos" (Heidegger, 2003a, p. 54). Otra vez, por ese lenguaje de Heidegger que llevó a Habermas a decir que Gadamer lo había urbanizado, hay que esforzarse por entender que no se hace aquí un llamado nacionalista y patriotero. Se trata, mejor, de la experiencia compartida, de lo que puede haber de sentir común en un momento histórico. 
Cuando Heidegger le atribuye a la poesía la fundación de la verdad, del ser, concentra en ella el valor que él le otorga al lenguaje ${ }^{9}$. En efecto, en la Carta sobre el humanismo Heidegger consigna que el lenguaje es la morada del ser y años después, en una de sus conferencias recogidas en De camino al habla, reitera que "algo es solamente cuando la palabra apropiada - y por tanto pertinente - lo nombra como siendo y lo funda así cada vez como tal" (Heidegger, 2002b, p.123). Por este motivo Heidegger no ve la poesía como un simple atractivo cultural, como un lenguaje cultivado. "Poesía, propiamente dicho, no es nunca meramente un modo (Melos) más elevado del habla cotidiana” (2002a, p. 3), la poesía es la manifestación más original del lenguaje, para Heidegger "el propio lenguaje es poema en sentido esencial” (2003a, p. 53).

Así, creo, gana claridad la tesis de Heidegger según la cual "únicamente donde haya Palabra habrá Mundo" (1989, p. 25). El lenguaje es la posibilidad de las distintas maneras de mirar(se) y de comprender(se), de hacer(se) y de rehacer(se). Dirá Heidegger, haciendo uso de una expresión de George, que "ninguna cosa es donde falta la palabra, es decir, el nombre. Solamente la palabra confiere el ser a la cosa" (2002b, p. 123). En su particularidad la poesía y en su generalidad el arte nos enseñarían el carácter esencial del lenguaje y, a la vez, nos revelarían nuestra posición en el mundo. Sin embargo, también nos dice Heidegger, "es más bien el hablar cotidiano un poema olvidado y agotado por el desgaste y del cual apenas ya se deja oír invocación alguna” (2002a, p. 23).

\section{VII}

A pesar del rebuscamiento retórico y de cierta oscuridad estilística, este pensamiento consigue perfilar, por una parte, una hermenéutica, una comprensión de lo que podemos ser, anclada a la historicidad y, por otra, una concepción del arte y del lenguaje disidentes de la instrumentalización. Ahora bien, no escapa a la observación en esta reflexión sobre el arte una suerte de trasunto mítico: la pérdida de una presunta unidad primordial. La crítica a una racionalidad y, en el fondo, a una epistemología proyecta una ontología: la verdad del ser como acontecimiento, como posibilidad accesible en la historia mediante el desapego de fórmulas para establecer relaciones. Esta manifestación de la verdad como consecuencia de una manera distinta de relacionarse con los otros y con lo que nos rodea abogaría por el establecimiento de vínculos. Los vínculos perdidos tras la muerte de los dioses serían recuperados y transfigurados, tal vez, mediante el tipo de relación que fomenta la experiencia del arte. ¿Puede el arte en nuestras sociedades contemporáneas generar sentido de comunión? Resulta dudoso si se plantea así, casi como una vuelta de lo sagrado. Por eso quiero pensar que se puede interpretar esa reflexión como un modelo. Quizás este planteamiento cobre otro sentido si en torno del arte se piensa, más bien, en que hoy lo que separa y vincula es lo político.

Y llegados a esa dimensión, encuentro inevitable mencionar un vacío. Se insiste en Heidegger en la emergencia de la verdad en la historia sin referir la historia material y concreta que rodeó la gestación de este pensamiento. Apoyado en la abstracción en que inevitablemente incurre el generalizar, ¿cómo preguntar si en la época de la imagen del mundo, en el tiempo en el que todo se ha hecho sustituible e intercambiable, los seres humanos no pertenecerán también a la categoría de las existencias sin referir una situación concreta? ¿Cómo tomar como presupuesto de la comprensión, de la búsqueda de una verdad que atañe al ser, nuestra historicidad sin referir la historia que se estaba escribiendo cuando este pensamiento se formulaba? 


\section{Notas}

${ }^{1}$ Este texto tiene origen en las indagaciones preliminares de la tesis doctoral Las novelas históricas de Germán Espinosa, presentada en la Universidad Autónoma de Barcelona para optar al título de Doctor en Teoría de la Literatura y Literatura Comparada.

${ }^{2}$ Evidentemente, aquí se reconoce uno (o el) de los móviles que impulsaron la hermenéutica de Gadamer, que tanto le debe a Heidegger.

${ }^{3}$ Gadamer explica que en el momento en que Heidegger elaboró su planteamiento acerca de la obra de arte, era corriente una idea acuñada por el neokantianismo encabezado por Nicolai Hartmann. Bajo esa idea "en un primer aspecto superficial, la obra de arte misma posee un carácter de cosa, que tiene la función de infraestructura sobre la que se levanta a modo de superestructura la auténtica configuración estética". Para mostrar la insuficiencia de este punto de vista, se sugiere, Heidegger comenzó por examinar el carácter de cosa de la obra de arte. Gadamer H-G. La verdad de la obra de arte. En Los caminos de Heidegger. Barcelona: Herder, 2002. Reproducido en http://www.heideggeriana.com.ar/gadamer/obra_de\%20arte.htm. Consulta en enero de 2014.

${ }^{4}$ No es de extrañar que el proceder que Heidegger sigue aquí y las conclusiones que expone puedan sorprender o generar rechazo. Me refiero, en particular, a la reacción que este pasaje suscita en Vicente Jarque: "En cuanto que «cosa», en efecto, el arte deberá ser diferenciado del mero instrumento. El filósofo trata de hacerlo recurriendo a un ejemplo: un cuadro de Van Gogh donde se representa un par de zapatos viejos que el propio Heidegger, acaso arbitrariamente, atribuye a una campesina. En un pasaje de notoria cursilería (hasta el insufrible Derrida lo ha calificado como «un momento de abandono patético») en donde se nos obsequia con una especie de «fenomenología» de la vida agrícola, el intérprete se esfuerza en que el cuadro «hable»". Jarque Vicente. Martin Heidegger. En Historia de las ideas estéticas y de las teorías artísticas contemporáneas, volumen II. Madrid: Visor, 1996, p. 100.

${ }^{5}$ Gadamer comenta que Heidegger "evita conscientemente cualquier recurso al concepto de genio de la estética clásica", y anota que cuando Heidegger introduce la noción de "tierra" como propia de la estructura de la obra "hay que entender esto dentro de la aspiración de comprender la estructura ontológica de la obra con independencia de la subjetividad de su creador o del observador" (Gadamer, 2002, s.p.)

${ }^{6}$ Gadamer recuerda que el significado de la palabra griega aletheia es verdad y Heidegger tradujo el término como desocultamiento, pues los griegos designaron a lo ente como lo desoculto, lo que correspondía a la representación correcta, alejada del error. Cfr. Gadamer H. G., 2002. Por su parte, Cristina Lafont dedica especial atención en su libro a la equivalencia que Heidegger estableció entre desocultamiento y verdad. "Lo que a Heidegger le interesa mostrar es que «la pregunta por la verdad es, en el fondo, la pregunta por la 'apertura' del 'ocultarse'» [...] es decir, precisamente la pregunta por el desocultamiento" (1997, pág. 150). Más adelante, Lafont se detiene en "La doble retractación de Heidegger en Zur Sache des Denkes", donde dice que "si se analiza detenidamente se puede comprobar que Heidegger, por un lado, revisa la tesis fuerte de la equivalencia de 'desocultamiento' y verdad” (pág. 208), pero, y es lo que debemos notar, “por otra parte, resulta igualmente claro que la forma en que para Heidegger el 'desocultamiento' está situado por encima de la corrección no se ve afectada por su retractación; que hay una primacía de la constitución de sentido frente a la comprobación de hecho, la cual ha de determinarse y explicarse de algún modo, sigue siendo para Heidegger una evidencia establecida” (pág. 214). Lafont, C. Lenguaje y apertura del mundo. El giro lingüístico de la hermenéutica de Heidegger. Madrid: Alianza Editorial, 1997. Así las cosas, no obstante la precisión que con los años Heidegger introdujo en su obra, la preeminencia de lo posible y del sentido se mantuvieron, que son aspectos que aquí se subrayan en la experiencia del arte.

${ }^{7}$ Gadamer comenta que la introducción de estos dos conceptos por parte de Heidegger significó un gran revuelo en su época, pues si bien la noción de mundo ya estaba presente en el pensamiento de Heidegger, aquí el término aparecía como propio del arte y con él el de tierra, que hasta entonces no lo había utilizado y era introducido con clara resonancia de su origen poético. Cfr. Gadamer H-G., 2002.

${ }^{8}$ Ya en esta obra Heidegger ha modificado la concepción del lenguaje que predomina en Ser y tiempo, donde lo observaba fundamentalmente como signo. Cristina Lafont opina que "en el contexto en el que surge esta afirmación [sólo donde hay lenguaje hay mundo] en El origen de la obra de arte no es sorprendente: Heidegger tiene que separarse — a la manera característica en la tradición Hamann-Herder-Humboldtde la concepción del lenguaje como instrumento [...] defendido en Ser y tiempo, a fin de poder dar cuenta del carácter «constitutivo» del lenguaje como «apertura del mundo»". Lafont, C., 1997, p. 118. 
${ }^{9}$ Valor a partir del cual Heidegger profundizará hasta llegar a un punto extremo — ¿cima o abismo?, del cual no me ocupo porque excede el alcance de este escrito - donde interroga al lenguaje diciendo que "no quisiéramos fundamentar el habla desde otra cosa que ella no sea, ni tampoco explicar otra cosa a través del habla", al punto que el lenguaje se hace tan inaprensible y Heidegger tan pleonástico que sólo puede responder que "El lenguaje habla". "En pos del habla y sólo acerca de ella quisiéramos meditar. El habla misma es: el habla y nada más. El habla misma es el habla. El intelecto educado por la lógica - calculador y por ello orgulloso - considera esta proposición una tautología que no dice nada. Decir dos veces lo mismo: el habla es el habla ¿acaso nos conduce esto a parte alguna? Pero no se trata de llegar a ninguna parte. Sólo quisiéramos de una vez llegar propiamente al lugar donde ya nos hallamos" (Heidegger, 2002a, pág. 12). Acerca de esta aporía del pensamiento de Heidegger sobre el lenguaje, Cristina Lafont explica en su libro que la “aproximación a la definición de la «esencia del lenguaje» como el «mostrar» debe situarse en el marco del programa de Heidegger de elaborar una nueva concepción no objetivista del lenguaje que pueda dar cuenta de su dimensión de «apertura del mundo»". Sin embargo, añade más adelante, "Heidegger identifica los «enunciados verdaderos» como correlato del «pensamiento objetivante» y con ello - totalmente en línea con su conocida crítica del pensamiento moderno como «Gestell»—- cree, al mismo tiempo, en la posibilidad de un presunto nuevo pensar «más riguroso que el conceptual» que estaría al alcance de la «poesía y la filosofía». Sin embargo, con estas especulaciones Heidegger toma una dirección en la que resulta más que problemático seguirle” (Lafont, 1997, pp. 137 ss.).

\section{Referencias}

Gadamer, H. G. (2002). La verdad de la obra de arte. En H. G. Gadamer, Los caminos de Heidegger. Barcelona: Heerder. Reproducido en http:/ / www.heideggeriana.com.ar/gadamer/obra_ de\%20arte.htm. Consulta en enero de 2014.

Heidegger, M. (1983). El cielo y la tierra de Hörderlin. En M. Heidegger, En Interpretaciones sobre la poesía de Hörderlin (pp. 163-192). Barcelona: Ariel.

Heidegger, M. (1989). Hörderlin y la esencia de la poesía. Barcelona: Anthropos.

Heidegger, M. (2000). Carta sobre el humanismo. Madrid: Alianza. Disponible en http://www. heideggeriana.com.ar/textos/carta_humanismo.htm. Consulta en enero de 2014.

Heidegger, M. (2001). La pregunta por la técnica. En M. Heidegger, Conferencias y artículos (pp. 9-32). Barcelona: Ediciones del Serbal.

Heidegger, M. (2002a). El habla. En M. Heidegger, De camino al habla (pp. 7-25). Barcelona: Ediciones del Serbal.

Heidegger, M. (2002b). La esencia del habla. En M. Heidegger, De camino al habla (pp. 117-160). Barcelona: Ediciones del Serbal.

Heidegger, M. (2003a). El origen de la obra de arte. En M. Heidegger, Caminos de bosque (pp. 11-62). Madrid: Alianza.

Heidegger, M. (2003b). La época de la imagen del mundo. En M. Heidegger, Caminos de bosque (pp. 63 90). Madrid: Alianza.

Heidegger, M. (2003b). La frase de Nietzsche "Dios ha muerto". En Caminos de bosque. Madrid: Alianza.

Heidegger, M. (2003c). La frase de Nietzsche "Dios ha muerto". En M. Heidegger, Caminos de bosque (pp. 157-198). Madrid: Alianza.

Heidegger, M. (2003d). ¿Y para qué poetas? En M. Heidegger, Caminos de bosque (pp. 199-238). Madrid: Alianza.

Lafont, C. (1997). Lenguaje y apertura del mundo. El giro lingüistico de la hermenéutica de Heidegger. Madrid: Alianza.

Vattimo, G. (1993). Poesía y ontología. Valencia: Universidad de Valencia.

Recibido: febrero 9 / Aprobado: mayo 28 de 2014 